\title{
The death penalty: a flawed debate
}

Media debate on the controversy over capital punishment in Papua New Guinea has been emotional. But the arguments have been flawed and distorted.

\section{By WILLIAM FEREA}

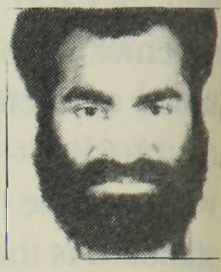

DEBATE through print and electronic media in Papua New Guinea has been mounting since 1989 over reintroduction of the death penalty. This reintroduction required Parliament to amend the Criminal Code, thus giving judges the option to choose the death penalty as punishment for wilful murder. The call for the death penalty stems from the alarming number of murders which are associated with the escalating law and order problems in Papua New Guinea since 1980 .

More weight supporting the death penalty surfaced when several prominent Papua New Guineans were brutally slain by thugs - Member of Parliament Malipu Balakau in 1989, former Police Commissioner Pius Kerepia in 1990, Lae businessman Leo Kende and family in 1994, and retired broadcaster JonBili Tokome in February $1995 .^{4}$ Actually, on 18 September 1991 the National Parliament restored the death penalty by amending the Criminal Code. Since then, judges have been reluctant to invoke the death penalty for wilful murder.

Those closest to such a sentence being passed was in 1994 when Justice Robert Woods convicted two men in Wabag for wilful murder. He refrained from imposing a death sentence when both solicitors and prosecutors argued against it. But on Friday, 17 February 1995, Justice Tracy Doherty handed down a landmark decision imposing a death sentence on Charles Bongapa Ombusu in Popondetta for rape and wilful murder. Ombusu is now appealing against the verdict to the Supreme Court of Papua New Guinea.

The Christian Argument against the death penalty

As expected, Justice Doherty's decision raised an even more intense debate on 
the justification of the death penalty. The country's newspaper and radio stations carried these opposing arguments. I was interested to know the ordinary Papua New Guinean's view on the issue, so I followed the Letters to the Editor sections of the newspapers. The popular argument against the death penalty in these letters seemed to be: Since Papua New Guinea is a Christian country, the death penalty is wrong and must not be imposed by the courts in cases of wilful murder.

A Taisen Asizo, of Tabubil, wrote to The National that 'thou shalt not kill' and that we must 'observe God's Ten Commandments where words of wisdom and peace of the mind are found'. Reporter Ethel Ageva mentioned the Rev Leva Kila Pat's description of the death penalty of Ombusu as 'very unfortunate'. The Rev Pat would rather approach the crime of murder through the Christian way where offenders would be 'born again' and 'become good Christians'.

In May 1995, at Goroka, the Catholic Bishops of Papua New Guinea and the Solomon Islands voiced their opposition to the death penalty. According to The National, 'reflecting on the latest document published by Pope John Paul II on the "Gospel of Life", the bishops said they felt deeply about the dignity and sanctity of human life under any circumstances,.

Now, at the outset the Christian Argument proposed by Asizo, Rev Pat and the bishops may seem convincing, but, as far as clear thinking is concerned, this argument is flawed. The Christian Argument may terrify people with God's wrath, but it will not convince any serious advocate of the death penalty to stop and rethink his/her position. This is for three reasons: First, the advocates can cling to the conviction that the church is espousing a hypocritical agenda society is encouraged to forgive criminals while the victims and their relatives continue to suffer prolonged psychological trauma. Second, there is concern that murderers may fake repentance or even remain indifferent to respecting human lives upon being offered solace through the Christian Argument. But, third and more importantly, the Christian Argument commits the grave fallacy of 'begging the question' (petitio principii). This misleading argument occurs when the following happens:

Anti-DP: ${ }^{9} \quad$ I oppose the death penalty.

Pro-DP: Why?

Anti-DP: $\quad$ Because Papua New Guinea is a Christian country.

Pro-DP: $\quad$ But, what if the death penalty is justified on the grounds that it is the only type of punishment which is equal in proportion to the severity of the crime of wilful murder?

Anti-DP: But look! In the Old testament the Bible says: 'Thou shalt not kill'. 


\section{WILLIAM FEREA}

Here, you can see that Anti-DP is arguing in circles. He hasn't said anything new apart from continuously repeating the authority of the Bible, Ten Commandments etc. Anti-DP is arguing from a dogmatic point of view. To try to convince Anti-DP to argue facts would be a futile undertaking. Such a line of argument (that of blind acceptance of God's command) can lead to disastrous consequences. Many of history's 'holy wars' and events like the Jim Jones and David Koresh tragedies arose from such dogmatic reasoning. In Papua New Guinea, arguments against death penalty must be grounded on facts, those that will reveal evidence and convince the advocate of the death penalty to stop and rethink his/her position. The following is an example of how Anti-DP can argue convincingly and simultaneously avoid the petitio principii flaw:

Anti-DP:

Pro-DP:

Anti-DP:
I oppose the death penalty.

Why?

Because (a) DP is not a deterrent to wilful murder, (b) most people commit murder without premeditation, (c) many murderers suffer from undetected mental illnesses, (d) there are gross inequalities in applications of the DP, (e) the innocent have been put to death, (f) DP obstructs justice, (g) there is no basis in savings-in-cost argument for life termers, (h) life termers rarely commit another homicide, and (i) DP is a crude and primitive form of retributive justice.

Pro-DP: What do you mean?

In reply to Pro-DP's question Anti-DP could go on and quote authorities like Victor Evjen who produced detailed explanations for the mentioned arguments against the death penalty. Anti-DP could even go on and produce data from research done by experts to substantiate his claims against the death penalty. I think that if we can formulate clear arguments to solve our worldly problems, like the death penalty, we can be more successful in producing well-informed decisions than recounting strict religious canons. These canons are a fundamental basis of our common law system in Papua New Guinea, but they have to be redefined to suit our social, economic, cultural and historical milieu. Indeed, the redefining of these Christian religious canons also ensures the very survival of Christianity.

\section{The Deterrence Argument for the death penalty}

One of Anti-DP's reasons for arguing his/her case is that the death penalty is not a deterrent to wilful murder. This is a direct reply to a common argument among advocates of the death penalty which claims that the death penalty will deter people from committing wilful murders. Ludwig Kembu, the Highlands police chief, is reported to be of the view that the death penalty will deter other Papua 64 PACIFIC JOURNALISM REVIEW 2:1 1995 
New Guineans from committing murders. ${ }^{12}$ Similarly, the Post-Courier reported PNG Police Commissioner Henry Tokam as saying that the death penalty was long overdue and that 'violent offenders must be served notice that lawabiding citizens ... are entitled to have their interests saved by law'.

Now, the Deterrence Argument appears to be convincing and indeed it has psychological appeal. Yet it must be said that the deterrence argument proposed by Pro-DP is neither correct nor incorrect. We simply have no way of knowing whether it can deter or not deter the crime of wilful murder. This has to do with difficulties in pinning down the correlation between the punishment of the death penalty and its effects on peoples committing wilful murders. A country or state could impose the death penalty, but murders increase due to inter alia factors like: (a) that country's acute economic and social conditions, (b) an easy accessibility to guns and weapons of destruction, and (c) the increase in number of free-roaming mentally retarded people who are bent on murdering others etc. On the contrary, a country may ban the death penalty, yet the rate of murders decreases anyway due to the reverse of the mentioned factors (a), (b) and (c).

The simple correlation of the number of murders in a state at a given time with the situation of imposition of the death penalty can be superficial. Indeed, I know from Victor Evjen that: 'no valid research, however, proves that the abolition of capital punishment leads to an increase in homicides nor that retaining it actually deters crime'. ${ }^{14}$ He based his view on a four-year study of capital punishment done by the 1953 Royal Commission in Britain which reached the same conclusion. Much hasn't changed since in terms of research findings that confirm the deterrence value of death penalty one way or the other. I am inclined to say that the Deterrence Argument proposed by the Pro-DP people does lead to an argument of false dilemma. It appears as follows:

Pro-DP:

Anti-DP:

Pro-DP:
I support the death penalty.

Why?

Because the presence of the death penalty means less murders while the absence of the death penalty leads to more wilful murders.

The Deterrence Argument leads people towards the fallacy of false dilemma where only the two extreme consequences of accepting or not accepting the death penalty is highlighted without any other alternatives. Actually, the Pro-DP people must have to cultivate other avenues for justifying the death penalty, rather than rely on the Deterrence Argument which is shown not only to be controversial, but also logically flawed.

\section{The Principle of Proportion}

It is difficult to kill a person as a form of punishment. But it is also difficult 


\section{WILLIAM FEREA}

contemplating allowing a wilful murderer to be cared for in prison or allowed possible parole when the victim's life is non-existent and relatives suffer a life long stress and trauma. The editorial of The National newspaper in February 1995 made the crucial point: 'Capital punishment is not against individual or human rights because when someone acts against the rights of others to their lives he loses his own right'. Jacques Barzun, in his article 'In Favour of Capital Punishment', strikes a similar chord (although in more forceful language), when he writes 'a man's inability to control his violent impulses or to imagine the fatal consequences of his acts should be a presumptive reason for his elimination from society. ${ }^{17}$ Forceful or mild may this preceding view be expressed, I think the essence of it is that there is such a crime called wilful murder of an innocent person(s) which no punishment can be proportionate to except the death penalty - whether it will deter or not deter murders is not the issue.

Now is the death penalty a form of 'payback' then? It may seem so. But what makes the death penalty different from the classic payback formula is that the victim's relatives are not 'paying back' on impulse. Rather, the state has the sovereign right to impose the death penalty if a person within its boundaries commits a gruesome offence like taking another person's life.

What is more, the state ensures that: (1) the defendant's constitutional rights are protected throughout the trial, (2) the defendant has access to a defence lawyer who is most certainly paid for by the state, (3) the defendant has fair access to the courts appeal system, and (4) failing appeals the defendant can ask for pardon from a committee chaired by the prime minister. Yet still the defendant will most certainly have the moral backing and lobby from human rights groups and the churches.

\section{Conclusion}

The issue of the death penalty in Papua New Guinea must be debated in the country's print and electronic media using clear and sound arguments. To bring in dogmatic and circular approaches like the Christian Argument and the ambiguous Deterrence Argument will shed little light and add insurmountable confusion to this important issue. Much of the debate was between ordinary people and some leaders through the Post-Courier, The National, the Times of Papua New Guinea and Roger Hau'ofa's NBC talkback show.

But journalists can help the public demarcate lines of sound and unsound arguments or to articulate their views on issues like abortion, euthanasia, poverty and the death penalty in a more cogent and logical manner. Only then can the public be said to be well-informed. But picking out flaws in arguments can be a tedious task for both philosophers and journalists alike. The task, 66 PACIFIC JOURNALISM REVIEW 2:1 1995 


\section{DEATH PENALTY}

however, becomes more manageable through practice.

Notes:

Malipu Balakau, a law graduate from the University of PNG was Student representative Council president in 1979 . He was regional member for Enga when murdered.

Pius Kerepia, of Buka, North Solomons province, was a former PNG Police Commissioner and former Correctional Service Commissioner. He was chairman of the Public Services Commission when murdered by a gang in Port Moresby in 1990.

Leo Kende, of Enga province, was a well-known businessman in Lae. He supported community groups, especially sports groups in Lae. He was murdered along with his Samoan wife and 10-year-old son as a 'payback' by tribesmen in the Western Highlands in 1994.

${ }^{4}$ Jon-Bili Tokome, from Buka in North Solomons Province, was a well-known National. Broadcasting Commission broadcast personality. He was murdered at his Boroko home while trying to defend his children from a gang. At the time of his murder, he was employed with a private company.

5ric Kone, 'Killer to hang,' The National, 21 February 1995.

'Taizen Asizo, 'Thou shalt not kill', Letter to the Editor, The National, 22 February 1995

Ethel Ageva, 'Very unfortunate: church leader', The National, 22 February 1995.

'Church opposes death penalty, The National, 10 May 1995.

DP stands for the death penalty.

10 'Bible does preach about punishing wrongdoers', Letter to the Editor, PostCourier, 23 February 1995.

${ }^{11}$ Victor Evjen, 'Against Capital Punishment', in J. Rachels, Moral Problems, New York: Harper and Row Publishers, Third Edition, 1979, pp 347-351.

2 'Sentence will deter killers: police chief', The National, 23 February 1995.

Cyril Gare, 'Death by hanging a bold move - Tokam', Post-Courier, 22 February 1995.

${ }_{15}^{14}$ Victor Evjen, op. cit.

A. Weston, A Rule Book of A rguments, New York: Hackett Publishing Company, 1987, p 88; and J. C. Merrill and S. J. Odell, Philosophy and Journalism, New York: Longman, 1983, pp 24-25.

17 'No Roman arena, please', Editorial, The National, 22 February 1995.

Jacques Barzun, 'In Favour of Capital Punishment', in Rachels, 1979, p 355.

18 'Death loses its meaning', Times of PNG, 18 May 1995.

William Ferea is Lecturer in Philosophy at the University of Papua New Guinea. He teaches a course in Journalism and Philosophy. 